\title{
Determinants of Capital Structure Decisions among Ethiopian Micro Finance Institutions: Panel Data Evidence
}

\section{Tesfaye Asefa*}

Department of Accounting and Finance, College of Business and Economics, Ambo University, Ethiopia

\begin{abstract}
Studies indicates that the capital structure of Microfinance Institutions have significant impact on the sustainability and outreach of these organizations. Hence, studying the factors that determine the capital structure of these organizations is imperative. Although the capital structure of financial firms have been studied by some scholars, such types of studies are rare in the MFI sector. Thus the purpose of this study is to investigate the determinants of capital structure in the Ethiopia MFI industry. To accomplish the objective of the study the quantitative research design is employed. The researcher used secondary data of 15 sample MFIs that fulfill the criteria of data availability from the MIX market database covering the period of 2003-2009. A panel data using Random Effect Multiple Regression model is used to analyze the standard determinants of capital structure. A sequential regression approach with two alternative specifications of model was employed. The research results show a negative and significant relationship between the MFI profitability, positive and significant relationship between MFI size, a negative and significant relationship between MFI tangibility and the leverage was found. On the other hand, the results show mixed results for the impacts of both age and growth rate on the leverage of Ethiopian MFIs. However, a negative but insignificant impact of business risk on leverage was found. The results of this study have delivered some insights on the capital structure theory. There could also be policies intended to encourage and creating conducive environment for MFIs to utilize debt as a viable source of finance in the era of increased commercialization of microfinance to meet their noble objective.
\end{abstract}

\section{Keywords: Determinants; Capital structure; MFI; Ethiopia}

\section{Introduction}

\section{Background of the study}

Microfinance refers to the provision of non-exploitative small-scale financial services to low-income clients. Microfinance Institutions have risen to the forefront as invaluable institutions in the development process. These institutions have expanded the frontiers of institutional finance and have brought the poor, especially poor women, into the formal financial system by enabling them to access credit in order to fight poverty [1]. According to the World Bank (2009) report approximately $80 \%$ of the world's 4.5 billion people are living in low and middle income economies lacking access to formal sector of financial services. Further, MFIs have become distinguished by their impressive low level of default rates on the average and return on equity ranging from 20 to 40 percent. According to Bogan [1], despite the successes of many MFIs, millions of low-income individuals in developing countries still do not have access to financial services. High operating costs and capital constraints within the MFI industry have prevented MFIs from meeting the enormous demand. Thus, institutional structure and capital flows to MFIs have become much more salient issues.

Currently, microfinance industry is in a state of flux. The nongovernmental organizations (NGOs) that once dominated that industry are transforming into licensed banks and non-bank financial intermediaries [2]. The donor agencies and soft loan providers want the MFIs to become independent of their help as they mature. So, it is not surprising that finding a new way to access capital by MFIs has become the trend in the industry as the lack of access to capital causes slower than optimal growth and large operational deficits. Research indicates that debt financing may be underutilized by MFIs as a new source of funding. Some advocates of innovation say transformation from nonprofit to commercial enterprises is the only way to go.

The determinants of capital structure are one of the most important debatable issues in the fields of corporate finance. A number of capital structure theories have been developed after the work of Modigliani and Miller [3] to explain many matters as the relationship between capital structure and firm value. Given the contribution of microfinance in the development process, factors that affect their capital structure have been overlooked by empirical studies. The study tries to borrow the determinants capital structure that were studied under banking industry and examines to what extent these factors affect leverage of MFI in Ethiopia.

Various studies examined factors that determine the capital structure of financial firms in general such as banks [4-6]. However, there is scanty literature in the capital structure of MFIs. But to mention a few addressed capital structure issues in this sector $[1,7,8]$. Kyereboah-Coleman [7] investigated the impact of capital structure on performance of Ghanian MFIs for the period 1995-2004 for 52 MFIs. Bogan [1] addressed capital structure issue in the global microfinance industry using a sample of top 300 MFIs for the year 2003. Kar [8] studied the impact of capital structure on the performance of MFIs from an agency theory point of view using a panel data set of 782 in 92 countries for the period 2000-2007.

Since the work of Modigliani and Miller in 1958 the irrelevances of capital structure a number of empirical works have been studied on the determinants of capital structure of firms. Most empirical finding

${ }^{*}$ Corresponding author: Tesfaye Asefa, Department of Accounting and Finance, College of Business and Economics, Ambo University, Ethiopia, Tel: +25192156979; E-mail: tesfayeasefa110@gmail.com

Received November 04, 2017; Accepted November 17, 2017; Published November 27, 2017

Citation: Asefa T (2017) Determinants of Capital Structure Decisions among Ethiopian Micro Finance Institutions: Panel Data Evidence. J Bus Fin Aff 6: 302. doi: 10.4172/2167-0234.1000302

Copyright: (c) 2017 Asefa T. This is an open-access article distributed under the terms of the Creative Commons Attribution License, which permits unrestricted use, distribution, and reproduction in any medium, provided the original author and source are credited. 
on the investigation of capital structure excludes financial firms from the sample in the sense that they are regulated and frequently viewed as "special" [4]. However, MFI require a separate treatment of study because they are historically donor funded (equity financed) with little use of debt, whereas banks are the opposite. They use more debt (savings) and little equity. The second gap is as most research finding have been done in developed nations a little is known in developing countries while MFIs are more important for this nations. In line with this, Octavia and Brown [5] added that it is imperative to understand the factors which drive the capital structure decision of financial firms. The main conclusions of these empirical studies are that industrial classification is an important to understand the determinants.

Despite an extensive empirical works that have been conducted on the topic for non-financial firms, little empirical is known in the financial firms sectors. A few research findings have focused on the determinants of capital structure of banking industry only. The capital structure of MFI is, however, still a relatively under explored area in the literature. Currently, there is no clear understanding, on how MFI choose their capital structure and what factors affect. In order to understand the capital structure of MFI their unique characteristics require separate study. The determinants of capital structure of MFI are undone in Ethiopia. This study addresses to fill this gap.

Therefore, more or less MFI industry is much related to the financial sector. As a starting point the determinants of capital structure of banking industry result would be taken to study the determinants of capital structure decisions of MFI. Additionally, a few literatures have provided evidence that are converged on a number of standard variables of financial firms that are reliably related to the capital structure of non-financial firms as reported by Gropp and Heider [4]. Especially, MFI would need to share some characteristics of nonfinancial firms. So this indicates there are common determinants of capital structure of MFI other than regulation that affect their financing decision.

Studying determinants of capital structure is important because it has an effect on the sustainability and outreach of these organizations [7]. This study is important for various stakeholders like management of MFIs, practitioners, researchers and policy makers in many ways. Management of MFIs can identify factors that hinder their MFIs from proper utilization of debt financing so that they can take some corrective actions that help them to their optimal debt-equity mix. This study is also important for researchers by showing the determinants of capital structure of MFIs in a poor country context using advanced econometric methods, panel data so that various extensions of this study be made. The study may also generate valuable information to inform policy makers like National Bank of Ethiopia (NBE) in creating conducive environment for MFIs to utilize debt as a viable source of finance in the era of increased commercialization of microfinance and expanded outreach goals.

The purpose of this study is to empirically examine determinants of capital structure 15 Ethiopian MFI that meet the criteria of data availability and to analyze using Panel regression model with a secondary data covering from 2003-2009.

\section{Statement of the problem}

After the birth of modern corporate finance during 1950s one of the most debatable issues is the capital structure theory. This theory has been extensively tested and studied from its inceptions. Especially after the work of Modigliani and Miller in 1958 until present the issue is going on. Though the area has been extensively studied by a number of scholars; the determinants of capital structure for financial firm's remains unresolved clearly in the recent literature. However, there are very few researches conducted weather this theory applies to financial institutions. Even from this study conducted at financial institution almost all address only banking institutions. Few of the studies conducted on microfinance institutions reported that the power of leverage is also tremendous in the performance of the industry $[7,8]$. Not surprisingly, higher leverage correlates with larger portfolio size.

Typically, microfinance find it difficult to borrow more than the equivalent of their equity. Obviously, this constrains their ability to grow. As MFIs become regulated, commercial funding sources are far more willing to lend to them. In 2001, the twenty regulated MFIs among the Micro Rate 29 had on average borrowed 4.5 times their equity compared to 1.3 times for unregulated [9]. According to AEMFI performance of the industry analysis (2010) report on average Ethiopian microfinance institution were able to obtain debt financing at amounts equivalent to 0.95 times of their equity. Moreover, to fill the existing debt financing gap the significance of intermediating deposits has in fueling growth and expansion in the industry need for capital constraint they have. However, the report indicates adding deposits in to debt/equity ratio the institutions remain underleveraged at 2 times which indicates debt financing is under-utilized in Ethiopian MFI industry. Various MFI industry reports suggest a debt/equity ratio that ranges between 4 times up to 8 times as an appropriate target. As such, the MFI has the potential to leverage its equity up to 11 times, the limit prescribed by the Basle Convention, the international capital adequacy standard for regulated financial institutions. For every dollar of equity, the regulated MFI can fund $\$ 11$ of assets. However, most regulated MFIs have not obtained such high leverage, due to the higher risks typically associated with a microloan portfolio. Banco Sol, which obtained its banking license in 1992, has maintained a relatively constant leverage ratio since 1994, fluctuating between 5 and 6 (Campion and White, 2001). In order for the MFI institutions to increase their leverage to the indicated target knowing the factors that affect capital structure becomes crucial. To my knowledge there is no empirical research conducted on the determinants of capital structure among MFI in Ethiopia. Therefore, this study tries to fill the gap in the existing literature and above all underutilization of debt financing in MFI by identifying the main factors that affect the capital structure of Ethiopian MFIs using panel data regression model.

\section{Objectives of the study}

General objective: The general objective of the study is to investigate the determinants of capital structure of Micro Finance Institutions in Ethiopia.

Specific objectives: a) To identify the MFI specific characteristics that determines the capital structure decisions of Ethiopian MFIs. b) To assess the dynamics of capital structure decisions of Ethiopian MFIs by comparing it across MFIs, over time or using industry average and the factors that affect the leverage of the industry.

\section{Research hypothesis}

The study examines the determinants of capital structure in MFIs that are considered as standard variables from various empirical results of studies that are related to financial institutions. The researcher tests the following alternative hypothesis on the relation between the leverage and the independent variables.

On the basis of the research problem identified the hypothesis that guide this research work are: 
$\mathrm{H}_{1}$ : There is a significant relationship between the MFI profitability and leverage.

$\mathrm{H}_{2}$ : There is a significant relationship between the MFI tangibility and leverage.

$\mathrm{H}_{3}$ : There is a significant relationship between the MFI growth and leverage.

$\mathrm{H}_{4}$ : There is a significant relationship between the MFI size and leverage.

$\mathrm{H}_{5}$ : There is a significant relationship between the MFI ownership and leverage.

$\mathrm{H}_{6}:$ There is a significant relationship between the MFI risk and leverage.

$\mathrm{H}_{7}$ : There is a significant relationship between the MFI age and leverage.

\section{Materials and Methods}

This section presents the research design and methodology that is employed to achieve the objective of the research work. As the study employs a quantitative approach it begins with the Quantitative research design, data type and source, population and sample design, goes on describing the econometric model and its specifications, operational definitions and measurements of the variables are dealt.

\section{Type of research design}

After reviewing and summarizing prior studies' findings pertaining to capital structure of financial firms especially in banking industry, the research design that is highly considered to investigate the determinants which are peculiar to MFI industry should be employed. In order to understand the determinants of capital structure of MFIs better in this study, the researcher employs quantitative approach. To accomplish this task, the researcher uses the descriptive technique where the study begins with the quantitative approach initially to collect and analyze secondary data of the sampled MFI in order to generalize results to population. Therefore, in this study the quantitate strategy with much higher weight is given to quantitative approach.

\section{Type and source of data}

To address the research objectives a panel data is considered to be the most appropriate. A panel data is the combination of cross-sectional and time series data. A panel data approach is more useful than either cross-section or time-series data alone. According to Baltagi [10] there are many benefits of using panel data among these: controlling for individual heterogeneity; gives more useful data, more variability, less collinearity among the variables, more degrees of freedom and more efficiency. While time-series is plagued with multicollinearity; Panel data has the ability to identify and measure effects that are simply not noticeable in pure cross-section or pure time-series data; Panel data are usually gathered on micro units, like individuals, firms and households. Many variables can be more accurately measured at the macro level, and biases resulting from aggregation over firms or individuals are eliminated.

The study is designed to examine the determinants of capital structure of MFI in Ethiopia. To achieve the objective of the study the researcher employed both secondary and primary data. The secondary data for this study is to be secured from various sources. The major data that is used in the empirical analysis is retrieved from www.mixmarket.org. The data is secured from MIXMARKET data base. This database compiles information on MFIs created in June 2002 as a private non-profit organization; the MIX (Microfinance Information eXchange) promotes the exchange of information within the microfinance sector. To procure this information, the MIX adopted a quality control system that awards diamonds on a scale of 1 to 5 . An MFI with a 4 and 5-diamond rating that has financial statements audited for seven years and data adjusted by a third party are considered for this study. Additionally, secondary data is also gathered from individual sampled MFIs and AEMFI were missing values are filled, to increase the quality of the data.

As the study empirically investigates the determinants of capital structure, the researcher employed 15 MFIs from the data base depending on the data availability of financial statement for the period of 2003-2009.

\section{Population and sampling design}

The empirical investigation on the determinants of capital structure of Ethiopia MFIs includes the institutions operating in the country. There are currently $28 \mathrm{MFI}$ operating in the country. To achieve this goal, a MFI that satisfies in terms of data availability of 7 years and with a 4 and 5-diamond rating are used as a unit of analysis. Using purposive sampling technique 15 MFIs from the industry where the financial statements required for 7 years to the most recent date were found legible. The sampling units that satisfy the criteria are: Metemamen, AVFS, Meklit, Gasha, Busa, Eshet, PEACE, Wasasa, SFPI, Wisdom ACSI, DECSI, OCSSCO, ADCSI and OMO.

The data for the remaining Microfinance institutions were not available and accessible in the data base as the criteria employed excludes from the sample. Despite the expectation that all MFI in the industry could meet the criteria employed as the units of analysis, the nature of panel data enables increase in the number of observation as the data are available across firms and over time $(7 \times$ $15=105$ ). Additionally, the employed sampling units are geographically disbursed throughout the country and have similar characteristics in terms of the governance structure and regulatory adherence, regional base which enables them to have similar ecological validity for a given industry to hold and supports the generalization of the finding of the study to the population. Besides, the RE model enables us to infer the results of sampling units to the population [11].

\section{Econometric model and specification}

Econometric model: In this study a Panel Regression Model is employed. In line with the previous determinants of capital structure of banking literature and other industries, the study employs Panel Data Multiple Regression Model to investigate the relationship between the explanatory variables and leverage.

Panel data can also control for individual heterogeneity due to hidden factors, which, if neglected in time-series or cross-section estimations leads to biased results [10]. The panel regression equation differs from a regular time-series or cross-section regression by the double subscript attached to each variable.

This study examines the determinants of the capital structure of sampled Ethiopian MFIs overtime using the following multiple regression model:

The general form of the model can be specified as:

$$
\mathrm{Y}_{\mathrm{it}}=\alpha+\beta \mathrm{X}_{\mathrm{it}}+\mu_{\mathrm{it}}
$$

with the subscript $\mathrm{i}$ denoting the cross-sectional dimension and $\mathrm{t}$ representing the time-series dimension. The left-hand variable, 
$\mathrm{Y}_{\text {it, }}$, represents the dependent variable in the model, which is the firm's leverage measured as debt-equity ratio. $\mathrm{X}_{\mathrm{it}}$ contains the set of explanatory variables in the estimation model, $\alpha$ is the constant and $\beta$ represents the coefficients.

The model specification: The regression model that is employed for this study is also in line with what was used in previous studies of banking sector, with some modifications.

The empirical model is given as:

$\mathrm{DE}_{\mathrm{it}}=+\beta_{1} \mathrm{AG}_{\mathrm{it}}+\beta_{2} \mathrm{SZ}_{\mathrm{it}}+\beta_{3} \mathrm{PR}_{\mathrm{it}}+\beta_{4} \mathrm{GR}_{\mathrm{it}}+\beta_{5} \mathrm{Rk}_{\mathrm{it}}+\beta_{6} \mathrm{OWN}_{\mathrm{it}}+\beta_{7} \mathrm{TG}_{\mathrm{it}}+\mathrm{e}_{\mathrm{it}}$

Where:

$\mathrm{DE}_{\mathrm{it}}=$ debt equity ratio (Total debt/Total equity) for MFI $\mathrm{i}$ in time $\mathrm{t}$

$\mathrm{AG}_{\mathrm{it}}=$ number of years functioning as MFI

$\mathrm{SZ}_{\mathrm{it}}=$ the size of the firm (log of total assets) for MFI $\mathrm{i}$ in time $\mathrm{t}$ time $\mathrm{t}$

$\mathrm{TG}_{\mathrm{it}}=$ tangible net fixed assets divided by total assets for MFI $\mathrm{i}$ in

$\mathrm{PR}_{\mathrm{it}}=$ earnings after interest and taxes divided by total assets for MFI $i$ in time $t$

$\mathrm{GR}_{\mathrm{it}}=$ growth rate in total asset for MFI $\mathrm{i}$ in time $\mathrm{t}$

$\mathrm{RK}_{\mathrm{it}}=$ absolute coefficient of variations in profit

$\mathrm{OWN}_{\mathrm{it}}=$ dummy variable 1 if MFI is government backed and 0 other wise $\mathrm{e}_{\mathrm{it}}=$ the error term.

\section{Method of data analysis}

The data analysis technique follows a quantitative approach by making use of quantitative analysis. The secondary data are collected and summarized in an excel data base containing the variables identified and exported to statistical software package known as STATA 11. Descriptive statistics such as percentage, mean, and frequencies, and graphical presentations and tables are used to decode the data which are collected from both sources. The quantitative analyses in assessing the determinants the capital structure of Ethiopian MFI are done using PDMRA. Panel data allows us to control for variables we cannot observe or measure like cultural factors or differences in business practice across firms, or variables that change overtime [11]. Thus, it accounts for individual heterogeneity. However, there are two techniques used to analyze panel data: Fixed Effects and Random Effects Model. When using FE model, we assume that something within the individual may impact the predictor variable and we need to control for this. This is the rational behind the assumption of the correlation between entity's error term and predictor variables. The rational behind RE model is that, unlike the FE model, the variation across entities is assumed to be random and uncorrelated with the predictor variables included in the model.
“... the crucial distinction between fixed and random effect is whether the unobserved individual effect embodies elements that are correlated with the regressors in the model, not whether these effects are stochastic or not." [12].

\section{Statistical tools and methods of data presentation}

The determinants of Ethiopian MFI are analyzed using Multiple Regression models with various assumptions about the relationships of the variables. To estimate the parameters in the model GLS technique helpful from the RE estimators on the basis of the test result. To test the relationship of independent variables with the dependent variable, the study employs some known statistical techniques that would enable the research finding be more accurate and reliable. Generally, the researcher uses STATA version 11, and Eviews 6 for the major two parts of the finding section namely descriptive statistics and empirical result. The first section descriptive statistics helps to measure the central tendency and dispersion. It helps to know frequencies, minimum, maximum, means and standard deviations for the dependent and independent variables. In the second section of the empirical result of the regression results of the study are reported.

\section{Results and Discussion}

In this section the researcher presents the main results and discussions of quantitative findings. Thus, the first part of the chapter deals with presentation of quantitative analysis of the study related to the first specific objective. The contents that are presented includes the descriptive statistics, tests of OLS assumptions, choice between fixed and random effect models and the findings of regression result.

\section{Empirical results}

Descriptive statistics: This part presents the descriptive statistics that summarizes the minimum, maximum, standard deviation, mean, median, and coefficient variations result of both the independent variables and dependent variable (Table 1).

From the above table the descriptive statistics of 15 sample Ethiopian MFIs of the year 2003 to 2009 are summarized for all variables in the study. The column observation gives the number of observations for which data are available for the study. Therefore, in this study there are 15 MFIs and 7 years totally 105 observations.

\section{Discussion of the Result}

The assumed hypothesis of $\chi^{2}$-statistic is that there no linear relationship among the variables, it means the value of Wald $\chi^{2}$ is nil, but here the value of $\chi^{2}$-statistics shows the highly significant linear relationship among the variables at $1 \%$ level of significance with overall good fitness of the overall panel multiple regression model. The value of $\mathrm{R}^{2}$ obtained from the model seems low in absolute sense. However, there is no absolute basis for comparison. According to

\begin{tabular}{|c|c|c|c|c|c|c|}
\hline Variable & Obs. & Mean & Std. Dev. & Min & Max & Cv \\
\hline DE & 102 & 1.79 & 1.49 & .01 & 7.68 & 0.83 \\
\hline ROA & 105 & .02 & .074 & -.35 & .26 & 3.7 \\
\hline$S Z$ & 105 & 17.66 & 1.80 & 14.37 & 21.57 & 0.102 \\
\hline TGB & 105 & .041 & .038 & .003 & .196 & 0.927 \\
\hline GRW & 105 & .369 & .899 & -.997 & 6.59 & 2.43 \\
\hline AG & 105 & 7.33 & 2.40 & 2 & 12 & 0.327 \\
\hline OWN & 105 & .267 & .444 & 0 & 1 & 1.66 \\
\hline RSK & 105 & -.144 & 1.86 & -9.05 & 4.45 & -12.88 \\
\hline
\end{tabular}

Source: Author's Own computation using Stata package 11.

Table 1: Descriptive statistics result. 
Greene [12], infact in using panel data, in cross section and in time series, the coefficient of determination of 0.5 and 0.20 , respectively can be sometimes noteworthy.

\section{Regression result}

This section presents the empirical result of the study that were hypothesized in the first section. The effect of determinants of capital structure is analyzed with panel data multiple regression analysis. The leverage is taken as dependent variable and size, profitability, age, growth, tangibility, ownership and risk are included as explanatory variables in this study.

The panel multiple regression requires the use of either of REM or FEM for estimating the parameters of the empirical data. As we have observed in beginning of this section the choice of the two models depends on Hausman specification tests. By running the Hausman test REM is accepted to be the appropriate model and the RE estimator is GLS. However, with the existence of the econometric problems the GLS estimator needs more efficient that is using the cluster robust standard (GLS). The regression results using cluster robust standard estimators of RE model which empirically tests the relationship between leverage (dependent variables) and the seven explanatory variables are discussed following this paragraph that describe the research finding of presenting in to 2 alternative specifications of the model.

Multicollinearity exists when there is a strong correlation between two or more predictors in a regression model. High level of collinearity increases the probability that a good predictor of the outcome will be found non-significant and rejected from the model implying the type II error. This problem makes it difficult to assess the individual importance of a predictor. So the model could include either one or interchangeably [13].

Among the different analytical strategies in multiple regression the sequential (hierarchical regression) has been selected as the method enable the researcher to specify the order of the independent variables according to their level of importance. Hence the general rule of the method is predictors should be entered in to the model by the researcher first in the order of their importance in predicting the outcome. The researcher normally assigns order of entry of variables according to logical or theoretical considerations. Here in this study the logical reasoning is more plausible than the theoretical aspect.

As per the VIF test of multicollinearity problem the researcher found that the individual VIF is less than 10 which is the benchmark of the test [11]. This result indicates there is no serious multicollinearity problem among the variables of the study. The correlation matrix also confirms the absence of serious problem of multicollinearity as the correlation coefficient is not exceeding 0.80 [14]. Although this evidence supports the absence of serious multicollinearity impacts have on the regression result, however due to high collinearity is shown between ownership and size of MFI the researcher is dictated to separately regress the multiple regression result in to two alternative specifications of the model. Therefore, the correlation coefficient of ownership and size of MFI indicates their level of collinearity is high but not serious. To better understand the separate regression effect, they have on the capital structure of MFI two regression specifications are used alternatively by adding and dropping the two variables (Table 2).

\section{Impact of profitability on leverage}

The results show that the coefficient of profitability is negative, and is highly significant at $1 \%$ level of significance with leverage. The coefficient magnitudes for the profitability are (-3.65) and (-5.34) in both specifications respectively with the same level of significance. As a result, the alternate hypothesis has been accepted that is profitability has a significant negative impact on leverage of MFI. The estimation results are consistent with our expectation that profitability is associated with a reduction of leverage. The findings of this study are consistent with prior empirical studies that leverage is negatively correlated with profitability that is, higher profitable firms use less debt. This shows that MFI with higher profits increase the level of internal financing. This means that retained earnings are preferred to debt because it is the easiest and quickest source of finance for most MFI in Ethiopia. The test of this hypothesis is in line with pecking order financial theory of capital structure. Also, in general, this finding is consistent with other

\begin{tabular}{|c|c|c|c|c|}
\hline \multirow{3}{*}{ Independent variables } & \multicolumn{4}{|c|}{ The effect of these explanatory variables on capital structure of MFI } \\
\hline & \multicolumn{2}{|c|}{$\begin{array}{l}\text { Model 2: With Ownership } \\
\text { Leverage (Dependent Variable) }\end{array}$} & \multicolumn{2}{|c|}{$\begin{array}{c}\text { Model 3: With Size } \\
\text { Leverage (Dependent Variable) }\end{array}$} \\
\hline & $\begin{array}{l}\text { Coefficients } \\
\text { (Robu. std err) }\end{array}$ & $\begin{array}{l}\text { z-value } \\
\text { (p-value) }\end{array}$ & $\begin{array}{l}\text { Coefficients } \\
\text { (Robu. std err) }\end{array}$ & $\begin{array}{l}\text { z-value } \\
\text { (p-value) }\end{array}$ \\
\hline ROA & $\begin{array}{l}-3.65 \\
(1.17)\end{array}$ & $\begin{array}{c}-3.12 \\
(0.002)^{*}\end{array}$ & $\begin{array}{l}-5.34 \\
(1.32)\end{array}$ & $\begin{array}{c}-4.03 \\
(0.000)^{*}\end{array}$ \\
\hline $\begin{array}{l}\text { OWN } \\
\text { (SZ) }\end{array}$ & $\begin{array}{c}1.45 \\
(.784)\end{array}$ & $\begin{array}{c}1.86 \\
(0.063)^{\star \star *}\end{array}$ & $\begin{array}{c}.442 \\
(.158)\end{array}$ & $\begin{array}{c}2.80 \\
(0.005)^{*}\end{array}$ \\
\hline TGB & $\begin{array}{l}-6.44 \\
(2.13)\end{array}$ & $\begin{array}{c}-3.02 \\
(0.003)^{*}\end{array}$ & $\begin{array}{c}-6.11 \\
(2.62)\end{array}$ & $\begin{array}{c}-2.33 \\
(0.020)^{\star \star}\end{array}$ \\
\hline GRW & $\begin{array}{l}-.134 \\
(.079)\end{array}$ & $\begin{array}{l}-1.69 \\
(0.091)^{\star \star *}\end{array}$ & $\begin{array}{l}-.120 \\
(.092)\end{array}$ & $\begin{array}{l}-1.31 \\
(0.191)\end{array}$ \\
\hline AG & $\begin{array}{l}.146 \\
(.066)\end{array}$ & $\begin{array}{c}2.22 \\
(0.026)^{\star *}\end{array}$ & $\begin{array}{l}.030 \\
(.084)\end{array}$ & $\begin{array}{c}0.36 \\
(0.718)\end{array}$ \\
\hline RSK & $\begin{array}{l}-.106 \\
(.180)\end{array}$ & $\begin{array}{c}-0.59 \\
(0.555)\end{array}$ & $\begin{array}{l}-.122 \\
(.181)\end{array}$ & $\begin{array}{c}-0.67 \\
(0.501)\end{array}$ \\
\hline Cons. & .800 & 1.12 & -5.75 & 2.39 \\
\hline Numb ob & 102 & 102 & 102 & 102 \\
\hline Wald chi2(6) & \multicolumn{2}{|c|}{$52.96(P=0.0000)^{*}$} & \multicolumn{2}{|c|}{$67.59(P=0.0000)^{*}$} \\
\hline R-square & \multicolumn{2}{|c|}{0.2018} & \multicolumn{2}{|c|}{0.2555} \\
\hline Firms & \multicolumn{2}{|c|}{15} & \multicolumn{2}{|c|}{15} \\
\hline Sig. & \multicolumn{4}{|c|}{ Level of significance *refers statistically significant at $1 \%,{ }^{* *}$ statistically significant at $5 \%$ and ${ }^{* * *}$ statistically significant at $10 \%$. } \\
\hline
\end{tabular}

Source: Author's own computation using Stata package 11

Table 2: Regression result Using GLS (cluster robust). 
empirical studies of banking sector [5,14-16]. However, the pecking order theory of MFI might differ from other firms in that it relies on external sources (initially donated equity) rather than internal sources (retained earnings) or profits generated and retained in the business. The pecking order theory of MFI might be reversed unlike other firms who finance using internal sources and then followed by debt and equity as a last resort.

\section{Impact of tangibility on leverage}

The regression result indicates that tangibility has a negative and significant impact on leverage of MFI. The coefficient magnitude is $(-6.44)$ and $(-6.11)$, respectively in both models respectively with different level of significance. This indicates that a negative relationship exists between tangible assets and leverage. This result is statistically significant at $1 \%$ and $5 \%$ level of significance respectively. As a result, the alternate hypothesis has been accepted that tangibility has a significant negative impact on leverage of MFI.

Theoretical research predicts positive relationship between tangibility and leverage. Prior empirical studies use net fixed assets scaled by total studies as its proxy and the findings are consistent with theoretical predictions. The findings of this study show different scenario. This is the main result for fact that most financial institutions do not lend to MFI because they assume loss of collateralization for debt increases the lenders risk. This result does not support the capital structure theory in principle that debt forms are used to finance tangible assets. This result is not consistent with other empirical studies due to the fact that tangibility has less to do with the objective of MFI. Therefore, this indicates the unique feature of these institutions in determining their capital structure. Generally, MFI industry is usually characterized by a relatively low level of fixed assets. Current assets can more easily be converted to cash and thus have more liquid capacity than fixed asset. In MFI industry the importance of current rather than fixed assets plays an important role in their decision to offer loans to their clients with high ratio of current to total assets, or a low ratio of fixed to total assets. This supply-side argument might explain why firms who own relatively low ratios of fixed to total assets. The findings of this study are similar to those reported by Octavia and Brown, and Gill et al. $[5,15]$.

\section{Impact of growth on leverage}

The regression results show that growth has a mixed result. The first model result indicates growth has a negative effect on leverage of MFI with coefficient values of (-.134) and the second model result indicates that growth of MFI has a negative impact but failed to show its statistical significance on the leverage of MFI with coefficients values of (-.120). Therefore, in the first model the alternate hypothesis that states growth has significant impact on the capital structure of MFI has been accepted with $10 \%$ level of significance. This indicates that faster growing MFI are less relying on external debt as the firms face greater uncertainty they tend to reduce their willingness to use debt.

Though it isn't statistically significant in the second model the regression result indicates a negative impact on the capital structure of MFI. This implies that growth is to measure growth rate of MFI is the annual percentage in total asset of firms that is not consistent with the firms which may be fundamentally different from nature of MFI. Therefore, growing MFI might place a greater demand on the internally generated funds. Consequently, MFIs with a relatively high growth rate will tend to look first at internally generated funds then to debt financing for their growth. This result is inconsistent with the findings of banking sectors. However, pecking order theory suggests that a firm's growth is negatively related to its capital structure. Myers and Majluf indicate that information asymmetry demands an extra premium for firms to raise external funds, irrespective of the true quality of their investment project. In the case of issuing debt, the extra premium is reflected in the higher required yield. High-growth firms may find it too costly to rely on debt to finance growth. Empirical studies that support a negative relationship between firm growth and leverage hypothesis are few [15]

\section{Impact of size on leverage}

The results indicate positive relationship between size and leverage with coefficient value of .442 . Therefore, the alternate hypothesis that states size of MFI has a significant impact on their capital structure has been accepted at $1 \%$ level of significance as it is indicated in the second model.

The implication of this finding is the larger (bigger) the MFI, the more external funds it will use. One reason is that, larger MFIs are more diversified and hence have lower variance of earning, enable them to manage high leverage. The providers of the debt capital are more willing to lend to larger MFIs as they are perceived to have lower risk levels. Besides, the size of MFI is highly correlated with the ownership of the MFI. Which is the main reason to separately regress in to Model 2 and 3 otherwise the separate effect of the two variables would have been difficult to identify. In general, the correlation of ownership and size of MFI in Ethiopia can be explained in such a way that the larger is the size of MFI, the higher tendency that it indicates they are governmentally backed Microfinance Institutions. Therefore, it isn't surprising that the larger the MFI is highly levered as they are governmentally backed institutions they enjoy the benefits of being guaranteed in accessing the commercial debt in relation to others.

This result supports the financial theory and is consistent with empirical evidence. Larger size firms enjoy economies of scale and creditworthiness in issuing debt and have bargaining power over creditors. These arguments suggest that larger firms have tendency to use higher leverage $[5,15,17]$.

\section{Impact of ownership on leverage}

The regression result indicates that a positive relationship between ownership structure and leverage with a coefficient values of 1.45 . Therefore, the alternate hypothesis that states ownership of MFI has a significant impact on their capital structure has been accepted at $10 \%$ level of significance as it is presented in the first model.

The theories of capital structure have less to say on the impact of capital structure of firms. However, few literatures have identified ownership as determinants of capital structure of firms. Majority of the empirical studies reported a positive relations ship between ownership and leverage. The proxy used to measure ownership in non-financial firms' empirical studies is the proportion of shares closely held at the firms. The researcher didn't find any empirical study that includes ownership as determinants of capital structure of financial firms mainly the banking sector. As there is no clearly defined ownership structure in MFI context, the researcher proxied ownership as a dummy variable which takes 1 if the institution is government backed and 0 otherwise.

The result indicates that ownership structure have a positive and significant impact on the capital structure of Ethiopian MFI. This indicates that MFIs that are owned by government development agencies are more levered than the others as a result these institutions are guaranteed by the government which reduces the lenders risk. 


\section{Impact of risk on leverage}

The regression result shows a negative relationship between MFI risk and leverage with coefficient values of (-0.59). Though the regression result found that MFI risk shows a negative impact on leverage it remains statistically insignificant. Therefore, the alternate hypothesis that states risk of MFI has a significant impact on their capital structure has been rejected because it is not statistically significant as it is presented in the first model. This implies that the business risk (earning volatility) of MFI has no significance effect in determining their capital structure as they are regulated business.

Several literatures support that MFI organizations are the risky area of business for their higher default amount of nonperforming loan they suffer. Additionally, this PAR risk is supported with the higher operating costs they face as a result of small loans provided to larger clients. In banking, one of the most important determinants of capital is related to the risk that banks have taken. Legal regulations relate the level of capital that banks must maintain with the level of risks that they carry. The main reason of this is that capital is viewed as a shield against unexpected losses and bankruptcy. The level of risk taken in banking can be measured by the share of the risk weighted assets in the bank's total assets (RISK=Risk Weighted Assets/ Total Assets) [18].

The relation between portfolio risk and capital adequacy in banking is negative. Normally, increasing risk level would require a higher level of capital. Perhaps the pattern of banks' capital structures is driven by risk, a variable that is included because it fails to show up as a reliable factor in the corporate finance literature on non-financial firms' leverage. Though risk is the major concern of financial firms leverage, the regression result shows a negative but insignificant impact. Consistent with findings $[4,5]$, firms with more volatile earnings tend to have lower leverage.

The negative coefficient on risk is consistent with both regulatory concerns and the corporate finance argument that debt is costly due to the expected cost of bankruptcy even though it is statistically insignificant. However, this might be due to the proxy used to measure risk at firm level. The business risk (volatility of earnings) at firm level is a standard measure of capital structure of non-financial firms measured as the ratio of standard deviation of profitability scaled by the mean profitability. In this study the standard measure of earning volatility were used. However, several literatures in the microfinance industry indicates the most commonly used risk measurement variable is portfolio risk over $>30$ days $(\mathrm{PAR}>30)$. It measures the specific risk related to the major operation of the firm which is measured as loan default due to clients more than 30 days. Therefore, business risk is preferred to the PAR because it is the crude measure of firms risk unlike the PAR which measure the risk pertaining to the potential inherited from the nature of the firm which less emphasize on the aggregate threat to the firm.

\section{Impact of age on leverage}

The result shows a positive relationship between MFI age and leverage with coefficient values of .146 . Hence, the alternate hypothesis that states age of MFI has a significant impact on their capital structure has been accepted at a $10 \%$ level of significance as it is statistically significant as reported in the first model. However, the result isn't statistically significant in the second model.

This implies that the larger the size of the institutions, the higher age that they dates back in operating in the country. More specifically the sampled MFI that were purposively selected on the basis of data availability and accessibility could show significant differences as larger institutions have many years of experience in operating in the industry which tend to give the opportunity to the access of external source of finance due to the experience curve they accumulate. So the regression result has shown significant impact age has on the leverage of Ethiopian MFI.

The researcher couldn't found empirical studies in the banking sector that included age as one determinants of capital structure. However, the result is consistent with the findings of Noulas and Genimakis [19] empirical studies from SMES. Due to restricted ability to acquire debt in the early stages of operation, a positive correlation is found between the age of the firm and its leverage in these studies. This implies that age is standard determinants of capital structure among firms.

\section{Conclusion}

This study has taken empirical step to examine capital structure of Microfinance Institution in Ethiopia. The study employs Panel Data Multiple Regression in analyzing the firm level determinants of capital structure of MFIs using Random Effects Model.

The result shows an empirical link between the determinants of capital structure of MFI and the capital structure theory. The key informant's perspective suggest that capital structure of Ethiopian MFIs industry are affected by collateral provision, capital adequacy (regulation), governance and ownership structure, business risk, historical records and outreach (women mix) in addition to the above standard determinants of capital structure.

It was noted that capital structure choice, as it was hypothesized, shows some consistency with a number of theoretical propositions. From this view the implication that the theories which explain the debt-equity choice in financial firms seem to be able to accommodate MFI capital structure decisions. However, ownership structure and governance consequences appear to be a material element for the understanding of unique behavior of MFI. Further studying of this fact had to be properly taken into consideration while drawing conclusions from the results.

\section{The following conclusion have been drawn from the study:}

The empirical results provide that there exist significant impacts of size, profitability, ownership, tangibility, age and growth on the capital structure of Ethiopian MFIs whereas risk has no significant impact on leverage of Ethiopian MFI industry.

Though debt financing has been accepted by the result to be beneficial for MFI industry to increase large scale of outreach and ensure the sustainability of the institutions in the long term. However, the practice of debt financing in the industry suffers from a number of factors in addition to the above empirically tested determinants. These includes: The ownership and governance structure are also the most determining factors for Ethiopian MFI capital structure dynamics. As the result indicates institutions that are government backed are guaranteed well than the others which are not. Therefore, when we relate this finding with the empirical result of ownership and size, have positive impact on the leverage of MFI, significantly affected positively by being government backed in accessing the commercial loans provision from the providers of capital to serve as a guarantee.

The creditworthiness of the institutions is checked by the providers of their capital and usually perceived as charitable institutions not viable business. The providers of capital don't see MFI as viable business 
because the operating costs of the MFI are believed to be high. The lenders attitude towards the institutions severely constrained the debt financing need MFI. This factor is related to the quantitative findings of profitability of MFI.

For institutions to be legible for the commercial debt at least nonperforming loan should be less than $5 \%$. This implies the business risk although it isn't significant affects the MFIs capital structure negatively.

Currently, the industry practiced $15 \%$ of saving mobilization (both voluntary and compulsory) over the period. This low performance of low saving in the industry is due to lack of promotion by the institutions for their business and products. Mainly, the roles of the institutional investors and such as small and medium financial institutions are not their focal point.

The institutions also can borrow only $5 \%$ of their equity capital (regulatory constraint). Above all this factors constraint the growth of MFIs industry in debt utilization unless the regulatory organ considers need to respond by relaxing the regulations.

\section{Recommendations}

On the basis of the above conclusions the following recommendations are forwarded by the researcher.

The majority of Ethiopian MFIs are lagging behind the industry average debt-equity ratio and other benchmarks reported and recommended by the sector analysts such as CGPA, MIXMKT industry report globally. Therefore, those MFIs which are highly profitable should use equity finance (less debt) as the finding indicates. Alternatively, as more profitable MFIs use retained earnings as a major means of financing they employ less debt. This implies that the industry is using more of donated equity, shareholder's capital and/ or retained earning rather than debt financing. This means those MFIs which have more preference towards equity should work aggressively to be profitable. To be profitable, the MFIs should manage their revenues and costs. Revenues should be pushed much whereas costs should be managed.

The most important factor that affects the debt equity (capital structure) of MFI is asset structure (tangibility). Tangibility has a negative and significant impact on the Ethiopian MFI leverage. This means those MFIs which have more collateral are accessing more debt as opposed to those MFIs with less collateral. This means collateral is highly required to access debt. As tangibility has a negative significant impact on leverage of MFI due to the fact the absence of the institutions investment in fixed asset can't go with the objective of the firm. However, MFI should at least increase the proportion of investment in fixed asset or else as it is practiced in other parts MFIs are using development funding and grants to guarantee commercial debt (AEMFI, 2009). The other factor that affects leverage of Ethiopian MFI is size. The results show that MFI size has a positive and highly significant impact on leverage of the sampled MFI. This means those MFIs who have more preference for debt should increase their size significantly by raising more external finance that is debt.

The other factors that affect the capital structure of MFI are growth rate of MFI and business risk of MFI. Though both variables have similar signs with the empirical finding of other study they failed to show significant impact consistently in the models to affect MFI capital structure. This implies that either the appropriate measurement proxy is not employed for MFI unique nature for the first variable and there exists absence of significant difference in accessing debt financing that would affect the leverage of the institution. Therefore, studying the impact of these variables on capital structure of MFI should consider the industry peculiarity rather than standard determinants of capital structure proxy used for all other firms.

Saving mobilization is hampered by lack of promotion on the part of MFIs about their products and the MFI are not using the potential of saving to the maximum. Therefore, the institutions should aggressively mobilize saving from institutional investors and promote themselves to the general public to exercise their power by the NBE regulation 40/96 as a financial intermediary.

The Ethiopian MFI industry should aggressively use debt financing as they are far away from the industry average and other benchmarks recommended by the sector analysts. The regulatory authorities of these sectors (NBE) should relax regulations for these sectors in order to achieve their major objectives of the institutions. At least the leverage of MFI should be relaxed to the Basel accord agreement allow for financial institutions to the maximum of $12 x$ leverage rather than $5 \%$ of their equity capital as per NBE. The major providers of capital in the industry RUFIP, CBE and IFAD should be empowered in borrowing from international finance organization which lend for MFIs at a very subsidized rate.

The government should consider the role of MFI industry playing in alleviating poverty and economic growth of the country by supporting and facilitating investment opportunities available for private investors in the sector. The participation of international NGOs as shareholders in the MFIs.

\section{References}

1. Bogan V (2008) Microfinance institutions: Does capital structure matter? Cornell University, Ithaca NY.

2. Hoque M, Chisty M, Halloway R (2011) Commercialization and Changes in capital structure in microfinance institutions: An innovation or wrong turn? Journal of Managerial Finance 37: 414-425.

3. Modigliani F, Miller MH (1958) The Cost of Capital, Corporation Finance and the Theory of Investment. American Economic Review 48: 261-297.

4. Gropp R, Heider F (2009) The determinants of bank capital structure. European Central Bank, pp: 1-50

5. Octavia M, Brown R (2008) Determinants of Bank Capital Structure in Developing Countries: Regulatory Capital Requirement versus the Standard Determinants of Capital Structure. The University of Melbourne working paper.

6. Iwarere HT, Akinleye GT (2010) Capital Structure Determinants of in the Nigerian Banking Industry: Financial Managers' Perspective. Pakistan Journal of Social Science 7: 205-213.

7. Kyereboah-Coleman A (2007) The impact of capital structure on the performance of microfinance institutions. The Journal of Risk Finance 8: 56-71.

8. Kar KA (2011) Does capital and financing structure have any relevance to the performance of MFIs? International Review of Applied Economics pp: 1-20.

9. Farrington $T$ (2008) Trends in Microfinance Capital structure. MicroRate, pp: $1-11$.

10. Baltagi B (2005) Econometric Analysis of Panel Data. (3rd edn.), John Wiley \& Sons Ltd, UK.

11. Baum FC (2006) An Introduction to Modern Micro Econometrics Using Stata Brighton, Massachusetts.

12. Greene WH (2003) Econometric Analysis. (5th edn), Pearson Education LTD, Prentice Hall, USA.

13. Field A (2005) Discovering Statistics Using SPSS. (2nd edn.), Sage Publications Ltd, London.

14. Gujarati DN (2003) Basic Econometrics. International edition. (4th edn.), McGraw-Hill Companies Boston USA. 
Citation: Asefa T (2017) Determinants of Capital Structure Decisions among Ethiopian Micro Finance Institutions: Panel Data Evidence. J Bus Fin Aff 6: 302. doi: 10.4172/2167-0234.1000302

Page 9 of 9

15. Gill A, Biger N, Pai Ch, Bhutani S (2009) The Determinants of Capital Structure in the Service Industry: Evidence from United States. The Open Business Journal 2: 48-55.

16. Gropp R, Heider F (2007) What can corporate finance say about banks' capital structures? Working paper, SSRN.
17. Amidu M (2007) Determinants of Capital Structure of Banks in Ghana: An Empirical Approach. Baltic Journal of Management 2: 67-79.

18. Asarkaya Y, Özcan S (2007) Determinants of Capital Structure in Financial Institutions: The Case of Turkey Central Bank of Republic of Turkey.

19. Noulas A, Genimakis G (2011) The determinants of capital structure choice: evidence from Greek listed companies. Applied Financial Economics 21: 379-387. 